\title{
Innovations and Support Institutions: the Ist Geographical Indication in Brazil
}

\author{
Yohanna Vieira Juk', Marcos Paulo Fuck²
}

\begin{abstract}
The Geographical Indication (GI) is an intellectual property instrument that may allow the adoption of innovations through the appreciation and insertion of origin labeled products in the market. The purpose of this research is to elucidate the role of $\mathrm{Gl}$ in the specific case of its concession in the Brazilian wine industry. Strategies embraced by producers and a national research institution (Embrapa Uva e Vinho) were aligned to international trends of technological patterns of wine production, noticing the GI as an instrument that could allow the entrance in the wine market as well as could increase the competition. The present analysis aims to prove the validation of this protection mechanism as an instrument that stimulates innovation (productive, organizational or marketing oriented), highlighting the role of support institutions and their possible impacts in the local scope, and also affecting institutional aspects that coordinate the concession of Gl in a macro level.
\end{abstract}

Keywords: geographical indication; vale dos vinhedos; innovation; support institutions; co-evolution.

\footnotetext{
1,2Postgraduate Public Policies Program, Federal University of Paraná, UFPR - ZIP: 802 10- I70, 632, Curitiba, PR, Brazil. e-mail: 'yohannajuk9I@gmail.com, ${ }^{2}$ marcospaulofk@gmail.com
} 


\section{Introduction}

New forms of consuming, producing and commercializing wines and spirits lead to a new configuration of the wine industry. New producing countries such as Australia, South Africa, United States, Argentina and Chile, known as the New Producing World, not only affected the supremacy of the Old Producing World (including in this category France, Italy, Portugal, Spain, among others), but also introduced new technologies and product innovations in the process of wine making. The products related to the New World received the technological wine designation, due to a production that prioritize quality which was achieved and built artificially, by the use of technologies (Giuliani et al., 20II). The new production contrasts to the terroir wines associated to the Old World production, which aimed a distinct product by appreciating its tradition and origin. This polarization between technological wines versus terroir wines, and in consequence, between New World versus Old World cannot be treated in a categorical way: both productions can be used simultaneously in a winery, in a region or even in a country. Niederle (20II) highlights that a technological production coexists with a terroir production and the investments for a distinctive production are aimed as well by New World countries.

The new context in which wineries find themselves demands original ways for differentiating a product. On this behalf, and considering particularly the wine industry, a specific form of intellectual property (IP) stands out by corresponding to the demand and productive configuration of both Old and New World: the Geographical Indication (Gl) . Products whose characteristics and qualities are linked to a specific origin can be protected by the $\mathrm{Gl}$ and according to international institution Food and Agriculture Organization (FAO) this could be the central link of a virtuous circle of quality, within a territorial system (FAO, 2009-2010). This new form of IP allows the adoption of innovation of several magnitudes as it demands the precise characterization of the productive process demanding a reorganization that prioritizes quality and differentiation. However, since the linkage to the origin is the essential characteristic of products that demand this instrument of IP, the $\mathrm{Gl}$ also enables the preservation of the terroir, the savoir-faire, by emphasizing the origin in production and also stimulating the insertion of products in new markets.

Although the origin of the $\mathrm{Gl}$ dates to French wine production in the 20th century, its magnitude as an IP instrument was acknowledged in the Trade-Related Aspects of Intellectual Property Rights (TRIPS) in 1994, which is considered the regulatory framework that generalize the concept of $\mathrm{Gl}$ in an international scope. What is argued by international organizations such as FAO (2009-2010) and
World Intellectual Property Organization (WIPO, [20--]) is that the evolution of the concept of Gl since its origin reveals an evolution of its function. New possible utilities are now associated to the $\mathrm{Gl}$, revealing the amplitude and the possibilities of its implementation. Both FAO and WIPO also stresses out the fact that the benefits of a Gl depends both on local factors, for instance: (i) the disposition of producers, (ii) the maturity of the local market, (iii) the linkage between product and their origin; and also macro level conditions, as: (iv) the existence of a solid and coherent legislation, (v) the existence and acting of support institutions (research institutions, capacitating institutions) and public policies that assist not only in the implementation but also in the maintenance of the $\mathrm{Gl}$ in a specific region.

This article aims to describe the implementation process of $\mathrm{Gl}$ in the Brazilian context, highlighting the Ist $\mathrm{Gl}$ in the South Brazilian region of the Vale dos Vinhedos for fine wines. This specific case enables the observation of the importance of a support institution - Embrapa Uva eVinho - that not only brought to light the magnitude of $G I$ as an IP mechanism and an instrument of rural development, but also changed the focus of the productive pattern and elevated the quality standard of fine wine production. The first section will briefly present the functionalities and potential effects of the Gl. Furthermore it will be described the legal framework in an international scope applied particularly in the Brazilian scenario with the institutional design resultant of the national legislation. Following, the fourth section will describe the introduction and implementation of the $\mathrm{Gl}$ in the Brazilian context, highlighting the active role of Embrapa Uva eVinho. The discussion of Nelson $(1994 ; 2006)$ of the importance of support institutions in the innovative process and in the industrial structure is aimed to discuss the pioneer action of Embrapa Uva e Vinho in the Gl implementation in Brazil, as well as considering the co-evolution of institutions through the arguments of Coriat and Weinstein (2002), allowing to understand the conflicts and the entrance of other public institutions in the thematic in the Brazilian context.

\section{Characteristics of Geographical Indications and the Regulatory Framework}

The $\mathrm{Gl}$ is an instrument that allows product protection and appreciation as well as access to new markets by associating a product's specific characteristics to the region of production. Bramley et al. (2009) affirm that the territorial linkage becomes a differentiation strategy to agricultural products . At the present time $\mathrm{Gl}$ is represented as a stamp in products' labels. Chiffoleau (2009) observes that studies concerning official quality stamps and labels, for example the Appelattion d'Origine Contrôlée (AOC) and Indication Géographique de Provenance, demonstrates that possessing an $\mathrm{Gl}$ is a way of preserving traditions and the savoir-faire, 
as well as a way of remaining in a competitive market. It is noted in international reports elaborated by FAO (2009$2010)$ and WIPO ([20--], 20I2) that the benefits generated by the implementation of the $\mathrm{Gl}$ exceed a general argument of rural development.

Different aspects are currently associated to the $\mathrm{Gl}$ such as an instrument that supports innovations in production techniques, preservation of territory and even promotion of regional tourism. Tonietto (2002), Cabral (201 I), Vargas (2007) and Farias andTatsch (2012) pointed that improvement innovations (organizational and marketing) and technological upgrading are possible results of a $\mathrm{Gl}$ implementation in the productive process. The main argument is that the concession of a Gl register per se does not guarantee any positive return to producers; other initiatives such as capacitating producers, supporting technological innovations and rural extension are essential to sustain and guarantee the appropriation of the benefits by the producers. Sustaining this argument, the $\mathrm{Gl}$ together with other factors allows the appropriation of innovational benefits by the producers, when assisted by support institutions. David Teece (1986) when discussing the apropriability of the innovative process stands out that intellectual protection (such as the $\mathrm{Gl}$ registration) alone cannot guarantee success and appropriation of positive effects - complementary assets such as support institutions or extensive assistance may ease the process of appropriation of innovational benefits by producers.

The $\mathrm{Gl}$ demands from the producers a precise characterization of the production, aiming the preservation of techniques or even the know-how in a way that traditional particularities are preserved. Niederle (20I I) stands out the fact that the complexity of a Gl relies on the adaptation of production to technological innovations that maximize efficiency, without losing the linkage to the traditional knowhow. It is through this process of recognition of a traditional production, by rethinking and reorganizing production, that innovations can be reported and incorporated, through the assistance of support institutions.

FAO (2009-20I0), WIPO ([20--]) and Giovanucci et al. (2009) argument that the potential benefits associated with a Gl are not easily achieved. The process is complex and dynamic, beginning with the elaboration of documents and materials (with the assistance of support institutions) to be submitted to an official organization, and proceeds to the post register and the continuity of production (also with the assistance of support institutions). Hence, the competitive environment in which the producers are inserted is a relevant factor to be considered when implementing a $\mathrm{Gl}$, together with the institutional design in a micro and macro level, aligned with the demands of the specific producers. In consonance with Nelson (2006) arguments, that although the firm is an important actor inside the innovative process, support institutions in many cases can be equally or even more relevant.

In order to protect producers from fallacious indications, Gl possess essentially three targets, according to FAO (2009-2010): (i) consumer's protection, correcting information asymmetries that exists between consumer and producer, along with proving guarantees of a minimum quality pattern; (ii) producer's protection, preventing that others may take advantage of their known reputation and notoriety and by that ensuring exclusivity for the production origin; and (iii) rural development, as a consequence of the process of product valorization and the institutionalization of reputation.

Through the recognition of the importance of $\mathrm{Gl}$ and its innumerous potentials effects, the instrument was integrated in the Common Agricultural Policy elaborated by the European Union as a manner of assisting small agricultural producers. According to Guedes and Silva (20I I), the policy possess a territorial bias, which puts $\mathrm{Gl}$ as a key innovative tool that not only includes producers in new markets but also guarantees the differentiation of the product founded on the territorial identification.

The regulatory trademark referent to $\mathrm{Gl}$, even though presenting a extensive historical of treaties and decrees, as mentioned previously, is the Trade-Related Aspects of Intellectual Property Rights (TRIPS) signed in 1994, which provides the concept adopted internationally of what is the GI. The cited Agreement, apart from conceptualizing $\mathrm{Gl}$, demands from the signing countries the elaboration of national regulation that conducts and provides the duties of institutions and producers concerning the thematic. WIPO (2012) stresses out the fact that there can be innumerous national approaches to $\mathrm{Gl}$, which will lead to a diverse numbers of institutional designs: the key motto is that there is no recipe, nor a model to be followed (Giovanucci et al., 2009). The legislation and therefore, the institutional design, must be coherent to the needs and characteristics of each country. Side with this argument, the Brazilian legislation shows a distinct configuration from the European. After signing the TRIPS, in 1996 it was elaborated the Industrial Property Law in Brazil, which classifies in both articles 177 and I78, the two modalities of Gl that are valid in the country: Indication of Origin and Designation of Origin (BRAZIL, 1996).

Although the legislation was elaborated in 1996, discussions concerning the effects and the use of $\mathrm{Gl}$ in Brazil dates to 1993, and were mainly reports elaborated by a public research institution (PRI), Embrapa Uva e Vinho, revealing a 
pioneer action of the mentioned institution - this subject will be detailed in the next section. The Industrial Property Law officialized the role of the institution incumbent of conceding the registration of the modalities of GI: INPI (National Institute of Industrial Property). Later on, in 2005 , another institution has its role legalized by the Decree 5.35I/2005, updated by the Decree 7.127/2010:The Ministry of Agriculture, Livestock and Supply is responsible for handling activities linked to $\mathrm{Gl}$ in Brazil. The 17 article of the 7.127 Decree/2010 assigned the Secretary of Agropecuary Development and Cooperative the function of "contributing to the formulation of an agricultural policy referring to the development of the agribusiness", apart from "planning, foment, coordinating, supervising and evaluating activities, programs and actions related to $\mathrm{Gl}$ and designation of origin". Hence, the role of the Ministry of Agriculture is not only to assist to the organization of the productive sector by subsiding and supporting the process of registration of a Gl, but also to assist and to supervise the pos-registration activities.

Even though there are only two official institutions whose activities are described in the Law 9.727/1996, a mapping of the 38 registered $\mathrm{Gl}$ in Brazil (up to December 2013) confirms the relevant participation of two other institutions: the Sebrae (Service supporting Micro and Small Enterprises) and Embrapa (Brazilian Enterprise in Agropecuary Research). The role of the four national institutions needs to be more deeply known since their activities conduct the implementations of $\mathrm{Gl}$ in all national territory. Their attributes and inner structures reflects in the policies that are being held in the thematic of $\mathrm{Gl}$, and the awareness of the other institutions' activities is important to understand if the actions are complementary or exclusive, and mainly if the comprehension of the function of $\mathrm{Gl}$ is shared by all national actors. Semi-structured interviews enabled the comprehension of the articulation and relations among the four cited institutions, which will be synthesized further.

\section{Institutional design}

The diversity of actors and the different levels of governmental engagement are vital to explain the singular institutional design formed to regulate and to support $\mathrm{Gl}$ products and regions (WIPO, 20I2). The institutional adjustment must be aligned to the producers' demands in a regional and national level; therefore the amplitude of action cannot be centralized in a federal unit and must be national embracing in order to achieve the most important actors regarding the GI: the local producers. In the Brazilian context the official institutions that concede the GI registration, INPI, interplay with producers mainly in the pre-registration stage, when demands can be made regarding the documents sent by the producers that aimed the $\mathrm{Gl}$ registration. The process is declared in a transparent manner, allowing the interaction and consultation of the process of register concession.After the $\mathrm{Gl}$ register is conceded, regulation does not exist: there is no monitoring of the registered Gls or a control by a third organization to attest the following of the approved production and a quality pattern. The control is done by the local producers, through a Regulatory Council within the Association of Producers that hold the Gl registration .This institution arrangement differ for example, from the European model, but according to Nelson (2006) analysis concerning support institutions, there does not exists a correct or efficient way that can be copied or transplanted with a guarantee of success, justly because of the dynamic and complex characteristic associated with technological innovations. Gl, as an inducer of technological innovations demands adaptable underlying institutions. Countries must be vigilant and flexible in order to create and adapt suitable institutions in a rapid and efficient way, that are capable of adjusting and/or creating opportunities and new fields of acting.

A generic description of Brazil's institutional design includes: a producers association that will demand registration to a regulator agency; the regulator agency; a promotion institution such as the Ministry of Agriculture acting in the identification of potential products and in the promotion and supplying of financial means for $\mathrm{Gl}$ projects; a research institution as universities or the Embrapa Uva e Vinho (a public research institution) that participate in the objective characterization of the production process enabling the recognition of the edafoclimatic characteristics that act in the quality of the product and, by these activities, assist in the elaboration of documents and materials; and finally an interprofessional institutions that assists in the professionalization of producers and in the management of production, which can be the case of Sebrae.

ISSN: 07I 8-2724. (http://www.jotmi.org) 
The definition and insertion of the institutions in the Brazilian scenario occurs after a period of structuring subsequent to promulgation of the Industrial Property Law, which characterizes a period of institutional learning on what is the $\mathrm{Gl}$ and which capacities could be developed and adapted by institutions for projects that accommodate the Gl concept.

Mascarenhas and Wilkinson (2014) stands out the fact that even with a juridical structure supporting Gls in Brazil, the delimitation of roles for the national actors and support institutions is not defined in the Industrial Property Law. Juk (2015) stresses out that there is not a common understanding of the functions of the Gl shared by all institutions and that the lack of an official instrument that demarcate the role and activities of each actor affects the national action concerning $\mathrm{Gl}$ projects and policies. According to Mascarenhas and Wilkinson (2014) the obstacle that prevents the Brazilian potential of products linked to origin is precisely the insufficiency of a public policy oriented to the recognition and maintenance of Gls. The commonality of arguments concerning the obstacles and demands from the four institutions relies in the need of a public policy that shall begin with the adjustment of the $\mathrm{Gl}$ legislation (Juk, 2015). Thus, the public policy depends on the update of the Law, with the availability of financial resources and lastly, the delineation of institutional roles.

The activities to sensitise and raise awareness of both producers and consumers consist another aspect of the obstacle to be overcome by the support institutions. According to Juk (2015) it is important to achieve an agreement on what is the $\mathrm{Gl}$ and what is the purpose of using this instrument of intellectual property. It is important to stand out a particularity of the Gl institutional arrangements that may also interfere and perhaps prevent the elaboration of a public policy of $\mathrm{Gl}$. Since it is important for the institutional design to be flexible, in order to adapt to the demand of specific producers, it is difficult to formulate a national policy that embraces these specificities, especially when Brazil's territorial extent is considered (Mascarenhas andWilkinson, 2014). This difficulty could be overcome, according to Mascarenhas and Wilkinson, when the policy embraces the Gl concept in its formulation. Coriat and Weinstein (2002), when discussing a critical analysis of the role of institutions in the institutional and evolutionary theories, stress out the process of co-evolution that occurs between institutions and technologies. In order to comprehend and to legitimate this process, authors argument that co-evolution is a result of continuous conflicts between two types of institutions:
Type I regards institutions that act to reinforce both firms and other institutions. Their action remains in delimitating paths of activities and also creating new paths to be followed. It can be seen as the juridical frameworks and also research institutions. It is possible to affirm, according to Coriat and Weinstein (2002) that some institutions define the rules for activities that are already happening, as other institutions create conditions allowing the emergence of new activities to be developed - this is the case of several scientific institutions which structures new activities, new strategies, new environments and new behaviors manners.

On the other hands there are the Type 2 institutions which relate to rules that are imposed by individual agents. They can complement or specify the type I institutions and contribute to the establishment and to the consolidation of behaviors. They are described by Coriat and Weinstein (2002) as contracts, conventions, and rules created by a group of agents, and unlike the type I institution, these type 2 institutions have limited scope and duration.

Coriat and Weinstein (2002) argued that the contradictions among all types of institutions in type I with institutions of type 2 are essential to comprehend the co-evolution process. Since institutions are in continual contradiction, legislation, rules of behaviors and new activities may evolve. Thus, divergences among institutions contribute to formulate and to promote productive change, resulting and affecting different forms of innovations (Coriat and Weinstein 2002). This situation can be applied to the specific case of public and support institution that acts in the Gl context in Brazil. The demand for a legislation change, for new strategies regarding GI policies demonstrate a similar situation as described by Coriat and Weinstein. The contradiction and divergence that exists, consists in the need to adapt institutions activities and juridical framework to the current contexts, aiming to assist with more efficiency the producers of products linked to the origin. Nelson (1994) aligned with Coriat and Weinstein (2002) arguments, stands out that institutions may coevolve and the same occurs to juridical structures, especially concerning intellectual property rights that must adapt and modify with new and modify technologies (Nelson, 1994).

\section{Ist Geographical Indication in Brazil and Embrapa Uva e Vinho pioneer action}

The introduction of the Gl discussion in Brazil initiated with a theoretical proposal and also presents the Embrapa acting in the field. Embrapa is one of the major public research institutions (PRIs) in Brazil. It was founded in April 1973 and it is associated with the Ministry of Agriculture. Its purpose was to execute activities of Research and Development (R\&D) and also aimed to transfer technologies created in the PRI. According to Fuck and Bonacelli (2009, p. 37) "the creation of 
Embrapa was an initiative of the federal government designed to centralize and focus agricultural technology policy by defining a single institutional trajectory". 1990 dates the period of restructure and institutional reorganization which enlarged Embrapa's mission in promoting research solutions, development and innovation for the sustainability of national agriculture. Through a decentralized action divided in 46 units, central units and international laboratories, it aimed to achieve its purpose.

The intention of the present analysis is to describe the action of one of the decentralized units located in south Brazil (in the state of Rio Grande do Sul) the Embrapa Uva e Vinho - focusing in researches and actions in grapes, wine, apple and other temperate fruits. The research activities in the mentioned unit rely in transfer of technologies associated with R\&D actions and the establishment of technical cooperation. Embrapa as an important PRIs in Brazil possess typical functions, according to Salles-Filho et al. (2000): (i) to generate strategic knowledge; (ii) to formulate public policies; (iii) to execute public policies; (iv) to generate opportunities of economic development; and (v) arbitrage. Salles-Filho et al. (2000) argument that each one of the cited functions places the PRIs in situations that demands responses of complex questions, as: Where to act? How to act? And, to act with whom? The authors through an analysis of the functions, processes and institutional trajectories point to elements that must be considered when discussing a PRI capability to adapt to changes, altering and redefining competences, strategies of extra-institutional relations and to redefine its internal organizational pattern. Based in an evolutionary analysis, Salles-Filho et al. (2000) stand out that PRIs "have evolutionary trajectories that redefine according permanently sets trade-offs" (Salles-Filho et al., 2000).

The competitive surrounding is another variable that must be taken into account and must be well known by a PRIs, since the market characteristics that surround these types of institutions demands the knowledge of the productive, innovative, organization and competitive process (SallesFilho et al., 2000). By comprehending its context the PRI can define research strategies and develop services. Thus, Salles-Filho et al. (2000) present three organizational principles that form a conduct that must be followed by PRIs: autonomy, flexibility and awareness. Autonomy relates to the institution's capability to define priorities, criteria, and norms that will rule its action. Flexibility is the organization of R\&D research and service, from an intern aspect. Awareness, which will be more deeply described, means the PRl's competence of perceiving tendencies.According to the authors, to achieve the awareness principle the institution must act rapidly when realizing external demands. This last mentioned principle explains the institution's aptitude of anticipating to changes and to interfere in a technological trajectory in its field of action. Bin et al. (2013) when analyzing agricultural PRIs highlights the fact that institutions, such as Embrapa "are effectively reorganizing to promote innovation process by creating tools, mechanisms and instances that build stronger links between R\&D and the needs of all sectors of society, rather than agriculture only" (Bin et al., 2013, p. 216).

Embrapa Uva e Vinho actions regarding the Gl instrument describe its aptitude of pursuing the principle of awareness. Reports describing the productive structure during the decade of 1980 commissioned by Embrapa Uva e Vinho, described that wine producers in the South Brazil, specifically in the state of Rio Grande do Sul, focused on the production of American grapes addressed to the commercialization of table wines. Wine-growing of the variety Vitis vinifera, addressed to fine wine production was decaying according to producers. The cited tendency could be proved by observing the total production area, with a reduction of 26,27 hectares for vinifera production and an increase of 4,04 hectares for hybrid and American species. Wine producers declared a minimum interest in Vitis vinifera growing due to the difficulties in the phytosanitary treatment and mainly due to the hardness of maintaining the product in a relevant position in the market. Not only the producers' opinion was contrary to a fine wine production, Freire et al. (1991) point a retraction of fine wine demand that resulted in a $26 \%$ reduction in commercialization of the product, reflecting in a lower search for viniferas varieties in the analyzed period.

The circumstances did not improve during the first years of the 1990's. According to Wright et al., (1993) the deeper analysis of Brazil's productive situation and perspective demonstrate other obstacles to fine wine producers. The commercial integration related to the creation of Mercosur that prioritize a major flow in the trade of South American countries. This particular event could increase competition in fine wine market, especially considering the entrance of Chilean and Argentinean wines. The perspective proposed by the authors suggested a strengthen of table wine production (including in this category grape juice production and a less sophisticated production), but mainly a more deep action of support institution including Embrapa Uva e Vinho and Universities in order to assist the productive actors to overcome the tough competition. As a result, the main argument was that the whole production chain should search for integrated responses in order to face competition with a appreciated product with improved quality. Embrapa's guideline, according to Wright et al. (1993), should be of prioritizing researches that concern to critical issues of the sector. 
Regardless of the described scenario, Tonietto (1993) proposed the use of the designation of origin, aiming its use in a marketing and competitive way, providing appreciation and differentiation of the national fine wine. Tonietto (1993) stands out that the Brazilian option for an open trade policy with objective actions, such as the advent of the Mercosur gradual removal of tariff barriers, outlines for the wine industry a more competitive scenario. In this context, it is vital to define actions that establish technological levels that could provide a qualitative increase in our wine industry, highlighting the origin and characteristics of national products. The author highlights the lack of juridical definition (reminding that the concerning Law was promulgated three years later, in 1996), but points the opportunity imposed by the economical condition of the period. Tonietto (1993) also stands out that similar initiatives were taking place in other countries of the New World of wine production, that prioritized quality of origin labeled products. The scientific effort, along with the technical-scientific support provided by institutions would be essentials factors for the first stage of the institutionalization of origin designation in Brazil. The economic conditions that characterized the wine industry during the 1990's demanded an action that could increase the consumers trust in a national product, and that could ease the entrance and establishment of quality fine wines within the international market.

The strategies embraced by producers and the national research institutions met international trends of a new production with a modernized technological standard for wineries within the New Producing World. Countries like Argentina, Chile and the United States in order to break through the international market, directed their efforts on a technological catching-up and on marketing strategies, in order to fit international standards.As highlighted by Giuliani et al. (20I I), process and product innovations have played an important role in the New World producers inclusion in the international market. Qualitative improvements and the relationship of narrowing initiatives between industry and universities are examples identified in Argentina, Chile and South Africa (Giuliani et al., 20I I).

The opportunity resulted in the change of the productive pattern concerning fine wine producers. Not only did Embrapa Uva eVinho assisted and supported Brazilian's first Gl product, other five Gls of wine products were registered up until 2013. The activities related to the implementation of the $\mathrm{Gl}$ in Vale dos Vinhedos, the first region to receive in 2002 the Indication of Origin modality in Brazil, consisted in the creation of the producers association, Aprovale, which is the official holder of the Gl register. The precise characterization of production resulted in a regulation of production stages that must be followed in order to have the "indication of origin" stamped in products' labels. Embrapa Uva e Vinho determined the extent of the territory and performed physical and geographical studies that characterize the region. Besides Embrapa Uva e Vinho, other support institutions assisted the first stage of the Gl implementation, including researchers at the University de Caxias do Sul, Embrapa Clima Temperado and Embrapa Florestas. The quality standards have been recognized and studied by a Regulatory Board created by the producers association that defined wine quality standards, and committed to ensure this standard through self-regulation. The partnerships with industry associations and institutions that promote technological infrastructure and training, such as Embrapa Uva eVinho as well as the creation of the Council contributed to stimulating innovation and for obtaining the Ist Brazilian GI in 2002, the Indication of Origin, and recently awarded the Designation of Origin in 2012 (Embrapa, 2015). Nelson arguments (2006) that although the firm is considered in many cases the main actor in the innovation process the presence of support institutions, in many cases, appear to have an equally or higher role. Cabral (20II) emphasizes the importance of the institutional arrangements formed in the Vale dos Vinhedos context, highlighting the significance of research institutions, for example, as essential to qualify and to improve the production process. However, it is also necessary to consider the case from a local perspective, due to the fact that local production systems have different innovative capabilities (Vargas, 2007). According to the latter author, "the competitive advantages and innovative dynamic in the wine industry are highly specific and based on local capacities" (Vargas, 2007).

In September 2012 it was conceded by the INPI the most rigorous modality $\mathrm{Gl}$ in Brazil in accordance with Resolution No. 75/2000: the Designation of Origin (DO). The DO possesses more specific quality criteria, resulting in a product with characteristics essentially linked to the production source. However, it is important to stands out that only 10 out of 26 associated wineries in the Aprovale met the production and quality standards approved in DO register. 


\section{Conclusion}

As highlighted by Giovanucci et al. (2009), one of the greatest skills of a $\mathrm{Gl}$ is its ability to serve as a framework with countless opportunities. Its applicability can vary for wine products, cheeses and services (a specific feature of the national legislation). Thus, to analyze their potential benefits it is necessary to take into consideration the specific context and the institutional arrangement of each product that aims this registration.

The Embrapa Uva eVinho, fulfilling its IPP function, observed an opportunity for Brazilian wineries to use the $\mathrm{Gl}$ as a competitive strategy that could ease the insertion in new market. Its function applied to the region Vale dos Vinhedos was directed to the differentiation and improvement of a quality pattern. The implementation process resulted in innovations of distinct natures, which were the result of the relationship between wineries and support institutions. In addition, it is important to emphasize that the support institutions such as the University of Caxias do Sul, but mostly, Embrapa Uva e Vinho were important to structure Aprovale and the production process so that the innovations of several magnitudes could be adopted.

The IG, analyzed through a neo-Schumpeterian perspective can be seen as an instrument that stimulates the adoption of many innovations both at the stage of implementation, with the organization of production and objective characterization of product quality, and in post-registration stage allowing the repositioning of the product and its insertion into unexplored markets. In consonance with the argument of David Teece (1986), it is possible to observe the IG, when applied to the Vale dos Vinhedos, as a complementary asset, that together with an underlying structure, allows the appropriation of innovative benefits by producers. That is to say, only the GI registration does not guarantee potential benefits; activities and innovations resulting from support institutions can validate $\mathrm{Gl}$ as a product differentiation and valorization instrument. GI applied to Vale dos Vinhedos reflects the international wine-producing countries trend, similarly with countries such as Argentina, Chile and Australia, which focused its activities in the technological catching-up and the suitability of the product for international consumption patterns, Brazilian wineries demonstrate, according to Vargas (2007), a level of technological sophistication consistent to international demand.

The present analysis reflects that the implementation of the $\mathrm{Gl}$ in Brazil occurred through the Vale dos Vinhedos in 2002. During this implementation period several institutions have entered the unofficial network of $\mathrm{Gl}$ at the national level, demonstrating a process of adaptation and coevolution between institutions and $\mathrm{Gl}$ in Brazil. The co- evolution process, as Coriat and Weinstein argued (2002) is possible due to the contradiction between institutions, and these conflicts result in arbitrariness and new rules or opportunities. The formulation of a public policy of Gl should be studied more profoundly, highlighting the definition of roles, but also recognizing that each product will require a different institutional arrangement adapted to their characteristics. What this analysis describes is that the results of a Gl can be identified more accurately when the productive and institutional context of each product is known. As argued by Giovanucci et al. (2009) one of the greatest skills of $\mathrm{Gl}$ is its ability to serve as a framework with countless opportunities, but this can also be its principal obstacle, due to the complexity of formulating a public policy that can attend to the economical, productive and institutional particularity of each product and still guarantee that benefits are appropriated by the local producers.

\section{About the Authors}

Yohanna Vieira Juk is a PhD student of the postgraduate Public Policies program of the Federal University of Paraná.

Marcos Paulo Fuck is a Professor at the Economics Department and the postgraduate Public Policies program at the Federal University of Paraná.

\section{End Notes}

I According to the Statistical report on World Vitiviniculture published by the International Organization of Vine and Wine (OIV), the mentioned countries contributed to $34 \%$ of the wine production worldwide.

2 The wine industry is remarkably present in the Gl world, including a specific section on their behalf in the TRIPS Agreement. However, other products with a linkage to their production origin demand this IP, such as coffee (Columbian Coffee), cheese (Roquefort Cheese), ham (Parma Ham), among others.

3 As pointed by Bramley (20II) in the context of growing competition in commoditized markets, the competitiveness is associated to scale production that allows decreasing cost with every produced unit. This allows producers to commercialize at lower prices. When dealing with traditional products, that many times are characterized by small scale productions, it is required the use of other instruments that adapt to the production needs and also insert the products in a more competitive market. Differentiation for traditional products is made through the linkage to the origin of production, providing information to consumers and establishing a quality pattern (Bramley, 20II). 
$4 \mathrm{Gl}$ regulation in Brazil presents an innovation when compared to Europe, for example. It is possible to concede the $\mathrm{Gl}$ registration to agricultural products as well as services that presents origin related characteristics.

5 This process is described in the INPI Resolution 75/2000 that contains rights and duties regarding $\mathrm{Gl}$ in Brazil.

6 What is observed is that in the context of contemporary markets, as pointed out by Buainain (2014, pp. 217), "the most attributes related to safety and quality of food and agricultural raw materials are imposed as standard, as a basic level and not as a differentiation factor that adds value to the product". Thus, "the production for safer and better food also requires technological and organizational changes that have strong socio-economic implications, and may even affect the competitiveness of producer groups, depending on the varying degrees of difficulty to meet the requirements" (Buainain 2014,p.218).The author is categorical, therefore, to say that the adaptation of producers to the new production standard is not a choice but a "survival" necessity because not meeting the new requirements of the market is a way to abstaining itself from it (Buainain 20I4, pp.2I5).

7 It can be said that, considering the market, the PRI is merely acting in accordance with a logic guided by profits, but understanding market mechanisms is essential because this is the environment in which it is placed. "In short, research institutions can be market oriented without being profit-seeking (Salles-Filho et al., 2000)".

8 The state of Rio Grande do Sul is responsible for $95 \%$ of the national wine production (Camargo et al., 2008).

9 The national wine production is simultaneous to Portuguese colonization, starting in the 16th century and was only consolidated as a commercial activity in the 20th century through the initiative of Italian immigrants established in South Brazil. The southern region was largely influenced by the culture of Italian immigrants that have contributed to the development and improvement of wine production (Wright et al. 1993).

\section{References}

BIN, Adriana et al. (2013) Organization of Research and Innovation: a Comparative Study of Public Agricultural Research Institutions. Journal of Technology Management and Innovation. 8, 209-2/8. doi: 10.4067/s07/827242013000300048

BRAMLEY, Cerkia. (20II) A review of the socio-economic impact of geographical indications: considerations for the developing world. Available at: http://www.wipo.int/edocs/ mdocs/geoind/en/wipo_geo_lim_I I/wipo_geo_lim_II_9. pdf.Accessed in 29 June 2015.

BRASIL. (1990) Decree 99.066 of 08 March 1990. Diário Oficial da União, Brasília, DF. pp. 4755

BRASIL. (20I0) Decree 7.I27 of 04 March de 20I0. Diário Oficial da União, Brasília, DF.

BRASIL. (1996) Law $n^{\circ} 9.279$, of I4 May 1996. Diário Oficial da União, Brasília, DF. pp. 8353.

BUAINAIN, Antônio Márcio. (2014) Alguns Condicionantes do novo padrão de acumulação da agricultura brasileira. In: Buainain, Antônio Márcio et al. (organizadores). $O$ mundo rural no Brasil do século 21: a formação de um novo padrão agrário e agrícola. Embrapa Estudos e capacitação, London. Pp. $211-239$.

CABRAL,Alexandre M.(20 I I) Proposta de EstruturaAnalítica para Suporte a Projetos de Preparação e Consolidação de Indicações Geográficas de Produtos Agropecuários. Master's Dissertation, Instituto Nacional de Propriedade Industrial.

CHIFFOLEAU, Yuna. (2009) From Politics to Co-operation: The Dynamics of Embeddedness in Alternative Food Supply Chains. Sociologia Ruralis, vol. 49. doi: $10.1111 /$ j.14679523.2009.0049I.x.

CORIAT, Benjamin; WEINSTEIN, Olivier. (2002) Organizations, Firms and Institutions in the Generation of Innovation. Research Policy, vol. 3I, 2002, pp. 273-290. doi: 10.1016/s0048-7333(0I)00I4I-x.

EMBRAPA - Empresa Brasileira de Pesquisa Agropecuária. Available at: http://www.cnpuv.embrapa.br/tecnologias/ig/ valedosvinhedos.html.Accessed in 29 April 2015.

FAO - Food and Agriculture Organization. (2009-2010) Linking Food, People and Places:a guide for promoting quality linked to geographical origin and sustainable geographical indications. Roma: FAO.

ISSN: 07 I8-2724. (http://www.jotmi.org) 
FARIAS, Claudio Vinícius Silva; TATSCH, Ana Lúcia. (20I2) Aprendizado, Inovação e Cooperação no APL Vitivinícola da Serra Gaúcha. In: Congresso da Sociedade Brasileira de Economia,Administração e Sociologia R ural, 50,Vitória.

FREIRE, Loiva Maria de Mello et al. (1991) Transformações na Estrutura Produtiva dos Viticultores da Serra Gaúcha 1985/I99I. Bento Gonçalves: EMBRAPA-CNPUV.

FUCK, Marcos Paulo; BONACELLI, Beatriz. (2009) Institutions and Technological Learning: Public-private Linkages in Agricultural Research in Brazil and Argentina. Journal of Technology Management and Innovation, 4(2), 3343. doi: $\mid 0.4067 /$ s07| 8-27242009000200003.

GIOVANUCCI, Daniele; RANABOLDO, Claudia. (2015) Markets and Geographical Indications of Origin. Synthesis of terra madre gathering and e-forum. Available at: http:// mpra.ub.uni-muenchen.de// 3552/I/MPRA_paper_l 3552. pdf Accessed in 02 February 2015.

GIULIANI et al. (20II) Innovation and Technological Catch up: the changing geography of wine production. Cheltenham: Edward Elgar. doi: 10.4337/97808579305 | 4.00006.

GUEDES, Cezar Augusto Miranda; SILVA, Rocio. (201I) Denominações Territoriais Agroalimentares, Políticas e Gestão Social:Argentina, Brasil e a experiência espanhola no contexto europeu. Universidad de Buenos Aires. v. I..

JUK, Yohanna Vieira. (20I5) Inovação e seus atores: as indicações geográficas no Vale dos Vinhedos. Master's Dissertation, Universidade Federal do Paraná.

MASCARENHAS, Gilberto; WILKINSON, John. (2014) Indicações Geográficas em países em desenvolvimento: potencialidades e desafios. Revista de Política Agrícola, n.2, Pp.I03-II5.

NELSON. (1994) The Co-evolution of Technology, Industrial Structure, and Supporting Institutions. Industrial and Corporate Change, v.3, p. 47-63. doi: 10.1093/icc/3.I.47.

NELSON. (2006) Institutions and Economic Growth: Sharpening the Research Agenda. Journal of Economic Issues. v. XLI. n. 2, p. 3|3-32|.

NELSON, Richard. (2008) What enables rapid economic progress: What are the needed institutions? Research Policy. 2008, v. 37. p. I-I I. doi: 10.1016/j.respol.2007.10.008.

OIV. Organisation Internationale de la Vigne et du Vin. (20I2) Statistics Department. Available at: http://www.oiv.int/oiv/ info/frizmiroivreport?lang=fr. Accessed in 23 June 2015.
SALLES-FILHO, S. L. M. et al. (2000) Ciência, tecnologia e inovação - A reorganização da pesquisa pública no Brasil. Campinas: Editora Komedi.

TEECE, David. (1986) Profiting from technological innovation: implications for integration, collaboration, licensing and public policy. Research policy, v (I5), p. 285-305. doi: 10.1016/0048-7333(86)90027-2.

TONIETTO, Jorge. (1993) Indicação geográfica Vale dos Vinhedos: sinal de qualidade inovador na produção de vinhos brasileiros. In: $\vee$ Simpósio Latino-Americano sobre Investigação e Extensão em Pesquisa Agropecuária/ $V$ Encontro da Sociedade Brasileira de Sistemas de Produção, 2002, Florianópolis, Anais. Florianópolis: IESA/SBSP, 2002. p. I 16. (CD-ROM).

TRIPS - Trade-Related Aspects of Intellectual Property Rights. Available at: http://www.wto.org/english/tratop_e/ trips_e/t_agm3b_e.htm. Accessed in 30 January 2013.

VARGAS, Marco Antônio. (2007) Learning, Localized Innovation and Competitive Performance: a preliminary analysis on the Brazilian system of innovation in wine. Centro de Gestão e Estudos Estratégicos Ciência, Tecnologia e Inovação, Rio de Janeiro.

WIPO -World Intellectual Property Organization. Definition of Geographic Indications, (20/2). Available at: http://www. wipo.int/edocs/mdocs/sct/en/sct_9/sct_9_4.pdf.Accessed in 4th de March 2012.

WIPO - World Intellectual Property Organization. Geographic Indications - an introduction. [20-]. WIPO Publication No. 952(E). Available at: http://www.wipo.int/ edocs/pubdocs/en/geographical/952/wipo_pub_952.pdf Accessed in 31 January 2015.

WRIGHT et al. (1993) Análise Prospectiva da Vitivinicultura Brasileira: questões críticas, cenários para o ano 2000 e objetivos setoriais. Bento Gonçalves, Embrapa. 